\title{
Efektifitas Model Pembelajaran Kooperatif Round Table terhadap Keterampilan Reading Comprehension pada TOEFL Ditinjau dari Motivasi Belajar Mahasiswa Politeknik Negeri Balikpapan
}

\author{
Elisabeth Milaningrum ${ }^{1 *}$, Lilik Damayanti ${ }^{2}$, \\ 1,2. Politeknik Negeri Balikpapan. \\ *elisabeth.milaningrum@poltekba.co.id
}

\begin{abstract}
Reading comprehension part is being the most difficult part in TOEFL based on the researcher's observations. Although they were given some strategies on reading comprehension, but there were still many students who found difficulty when solved the problems. One of the external factors cause the lower reading comprehension skills of students that is influenced by teaching method in the classroom and students' learning motivation as internal factors. The method which was applied in this research was experimental study in order to know the difference and effect between Direct Instruction teaching method and Roundtable Cooperative teaching method for teaching reading comprehension on TOEFL. The data were analyzed by using multifactor analysis of ANOVA $2 \times 2$ and tukey test. Based on the results of the analysis, it can be concluded that Roundtable Cooperative teaching method is significantly different from Direct Instruction teaching method to teach reading comprehension on TOEFL. The reading comprehension of the students who have high motivation is significantly different from that of those who have low motivation. Roundtable Cooperative teaching method is more effective than Direct Instruction teaching method to teach reading comprehension on TOEFL for the students who have high motivation; however for the students who have low motivation, Direct Instruction teaching method is more effective than Roundtable Cooperative teaching method to teach reading comprehension on TOEFL. Thus, there is an interaction between teaching methods and students' learning motivation for teaching reading comprehension on TOEFL. The effectiveness of the teaching method depends on the degree of the students' motivation.
\end{abstract}

Key word: teaching methods, reading comprehension, and learning motivation.

\begin{abstract}
Abstrak
Bagian reading comprehension menjadi bagian tersulit pada TOEFL berdasarkan hasil pengamatan peneliti . Meskipun sudah diberikan strategi - strategi pada reading comprehension, namun masih banyak mahasiswa yang merasa kesulitan ketika menyelesaikan soal tersebut. Salah satu penyebab faktor eksternal rendahnya keterampilan reading comprehension mahasiswa yakni dapat dipengaruhi oleh model pembelajaran di kelas dan motivasi belajar siswa sebagai faktor internal.Penelitian ini menggunaan penelitian eksperimental semu untuk mengetahui perbedaan dan efek dari model pembelajaran langsung (Direct Instruction) dan model pembelajaran kooperatif Roundtable. Data dalam penelitian ini dianalisis menggunakan uji statistik ANOVA dua jalur dan uji Tukey sebagai uji lanjutan. Hasil analisa menunjukan bahwa model pembelajaran Kooperatif Roundtable signifikan berbeda dengan model pembelajaran langsung. Kemampuan reading comprehension mahasiswa yang memiliki motivasi belajar tinggi signifikan berbeda dengan yang memiliki motivasi belajar rendah. Model pembelajaran kooperatif Roundtable lebih efektif diterapkan bagi mahasiswa yang memiliki motivasi belajar tinggi sedangkan model pembelajaran langsung ( Direct Instruction ) lebih efektif diterapkan bagi mahasiswa yang memiliki motivasi belajar rendah. Oleh karena itu, dapat disimpulkan bahwa terdapat interaksi antara model pembelajaran dan motivasi belajar siswa untuk mengajar reading comprehension pada TOEFL. Keefektifan model pembelajaran tergantung pada tingkat motivasi belajar siswa.
\end{abstract}

Kata kunci : model pembelajaran, pemahaman mambaca, motivasi belajar 


\section{Pendahuluan}

\subsection{Latar Belakang}

Seiring dengan era globalisasi, setiap pencari kerja diharapkan memiliki kompetensi yang memadai untuk dapat bersaing di perusahaan-perusahaan multinasional. Setiap lulusan Politeknik Negeri Balikpapan diharapkan dapat menggunakan bahasa Inggris secara fasih dan memiliki skor TOEFL yang tinggi sebagai alat ukur kemampuan berbahasa Inggris. Menyadari pentingnya keterampilan berbahasa Inggris dan skor TOEFL, maka Politeknik Negeri Balikpapan menetapkan skor TOEFL terendah adalah 450. Akan tetapi, hingga saat ini hasil skor TOEFL mahasiswa masih banyak yang dibawah 450 dan hanya beberapa mahasiswa yang pandai saja yang bisa mencapai target. Berdasarkan pengamatan tim dosen bahasa Inggris, bagian reading comprehension test menjadi bagian tersulit. Meskipun sudah diberikan strategi strategi pada reading comprehension, namun masih banyak mahasiswa yang merasa kesulitan ketika menyelesaikan soal tersebut.

Menurut Johnson (2000 : 25), ada dua penyebab rendahnya prestasi keterampilan reading comprehension. Hal ini berasal dari faktor eksternal dan internal. Salah satu penyebab faktor eksternal rendahnya keterampilan reading comprehension mahasiswa yakni dapat dipengaruhi oleh model pembelajaran di kelas yang dilaksanakan oleh dosen. Peneliti telah meneliti dua model pembelajaran yang memiliki perbedaan perspektif dan prinsip didalam proses prosedur pengajaran. Menurut Borrich (1996: 224) model pembelajaran kooperatif RoundTable melibatkan mahasiswa secara aktif dalam pembelajaran dengan melakukan diskusi dalam kelompok, kemudian setiap anggota kelompok diwajibkan menuangkan pendapatnya secara bergantian pada selembar kertas, sedangkan menurut Kardi (Trianto, 2011: 30) model pembelajaran langsung (Direct Instruction) dimana pembelajaran berpusat pada dosen sebagai penyedia informasi utama. Berdasarkan hasil penelitian Duff (2012) yang membandingkan model pembelajaran langsung (Direct Instruction) dengan model pembelajaran kooperatif menyatakan bahwa secara umum, pelajaran yang diajarkan dengan kooperatif akan lebih menyenangkan dan mahasiswa dapat menemukan hubungan dengan kehidupan mereka sendiri. Model pembelajaran kooperatif memberikan mahasiswa kesempatan untuk memahami material dengan lebih baik. Selain itu, Penelitian Arra, dan D'Antonio (2011) yang membandingkan secara kuantitatif tiga tipe model pembelajaran kooperatif yaitu ThinkPair-Share, Three-Step Interview, dan RoundTable menyimpulkan bahwa 


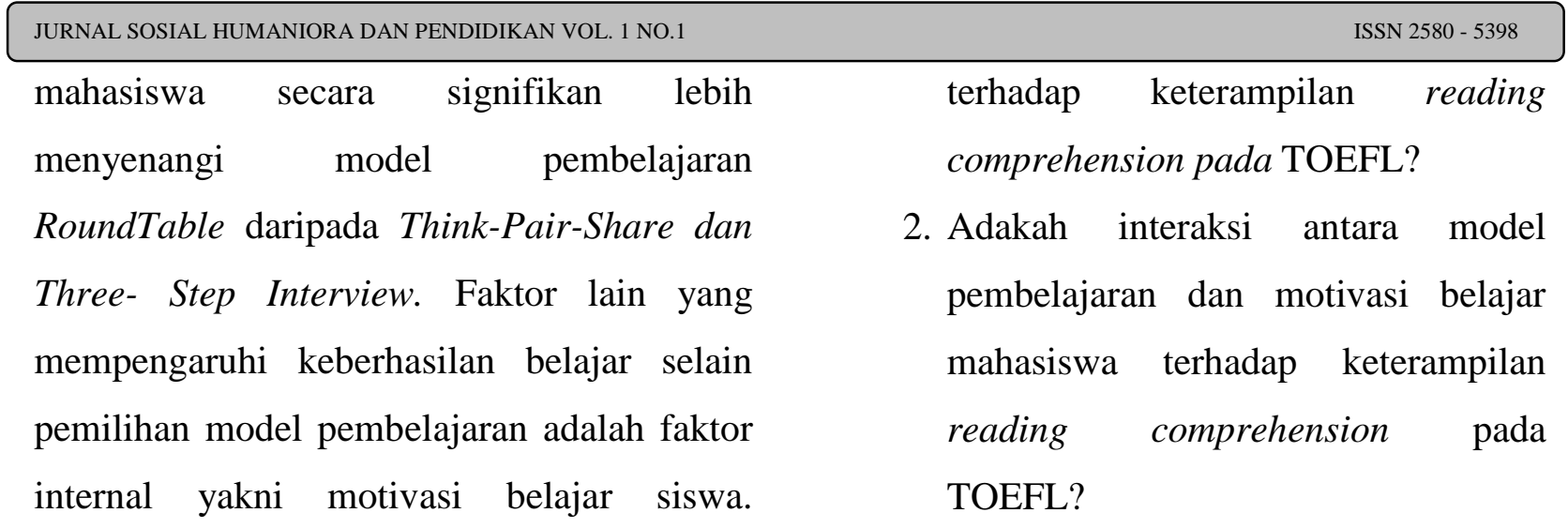

Menurut Weiner (Elliot, 2000: 332)

menyatakan bahwa motivasi belajar memiliki peran yang besar dalam menentukan keberhasilan proses pembelajaran untuk mencapai tujuan pembelajaran dan keaktifan siswa. Seseorang melakukan suatu usaha karena adanya motivasi. Motivasi belajar dapat timbul karena faktor internal dan eksternal (Sardiman 2006:89). Hamzah (2007:23) menyebutkan bahwa faktor internal dapat berupa hasrat dan keinginan berhasil, dorongan kebutuhan belajar, dan harapan akan cita-cita. Sedangkan faktor eksternal dapat ditimbulkan adanya penghargaan, lingkungan belajar yang kondusif, dan kegiatan belajar yang menarik.

\subsection{Rumusan Masalah}

Berdasarkan latar belakang penelitian diatas, maka peneliti merumuskan beberapa permasalahan yakni:

1. Apakah model pembelajaran kooperatif RoundTable lebih efektif dari pada model pembelajaran langsung (Direct Instruction)

\subsection{Tujuan Penelitian}

1. Untuk mengetahui apakah model pembelajaran kooperatif RoundTable lebih efektif dari pada model pembelajaran langsung (Direct Instruction) terhadap keterampilan reading comprehension pada TOEFL.

2. Untuk mengetahui pengaruh model pembelajaran dan motivasi belajar mahasiswa terhadap keterampilan reading comprehension pada TOEFL.

\section{Metoda Penelitian}

\subsection{Metodologi Penelitian}

Penelitian ini menggunaan penelitian eksperimental semu dengan menggunakan desain faktorial $2 \times 2$ untuk mengetahui perbedaan dan efek dari model pembelajaran langsung (Direct Instruction) dan model pembelajaran kooperatif Roundtable.

\subsection{Populasi, Sampel, dan Teknik Pengambilan Sampel}

Penelitian ini dilakukan di Politeknik 
Negeri Balikpapan dengan populasi mahasiswa semester 2 Politeknik Negeri Balikpapan. Sampel yang diambil dalam penelitian ini menggunakan dua kelas yakni satu kelas eksperimen dan satu kelas kontrol. Dalam pengambilan sampel menggunakan teknik cluster random sampling. Setiap kelas dibagi ke dalam dua kelompok yakni kelompok mahasiswa yang memiliki motivasi belajar tinggi dan mahasiswa yang memiliki motivasi belajar rendah.

\subsection{Teknik Pengumpulan Data dan Analisis Data}

Data tentang keterampilan reading comprehension pada TOEFL diperoleh dengan menggunakan test dalam bentuk pilihan ganda dan data mengenai motivasi belajar mahasiswa diperoleh dengan menggunakan angket. Data dalam penelitian ini dianalisis menggunakan uji statistik ANOVA dua jalur dan uji Tukey sebagai uji lanjutan.

\section{Hasil Penelitian}

\subsection{Deskripsi Data}

Hasil penelitian ini dibagi menjadi menjadi beberapa bagian, yakni deskripsi data , tes normalitas dan homogenitas, tes hipotesis yang meliputi uji ANOVA $2 \times 2$ dan uji lanjutan tukey. Dalam mengklasifikasikan mahasiswa yang memiliki motivasi tinggi dan motivasi rendah. . Seorang siswa yang memiliki motivasi tinggi akan setuju dengan pilhan positif dan tidak setuju dengan pilihan yang negative (Tuckman, 1978: 179-181). Penulis mencari mean, modus, dan median. Setelah diklasifikasikan, maka dilakukan uji normalitas dan homogenitas. Uji normalitas digunakan untuk mengetahui apakah sampel merupakan distribusi normal dan uji homogenitas digunakan untuk mengetahui apakah data yang diperoleh homogen.

Tes dapat dilakukan setelah hasil dari normalitas dan homogenitas data dapat terpenuhi.

\subsection{Tes Hipotesis}

Data dianalisa menggunakan multifactor analysis of variance (ANOVA) $2 \times 2 . \mathrm{H}_{\mathrm{o}}$ ditolak jika $\mathrm{F}_{\mathrm{o}}$ lebih tinggi daripada $\mathrm{F}_{\mathrm{t}}$ $\left(\mathrm{F}_{\mathrm{o}}>\mathrm{F}_{\mathrm{t}}\right)$. Hal ini berarti ada perbedaan signifikan. Setelah mengetahui bahwa $\mathrm{H}_{\mathrm{o}}$ ditolak, analisa dilakukan untuk mengetahui perbedaan antara kedua kelompok dan cells menggunakan tes Tukey. Untuk mengetahui kelompok mana yang lebih baik, skor ratarata kelompok dan cells dilakukan perbandingan. ANOVA $2 \times 2$ dan tes Tukey adalah sebagai berikut:

Tabel 1 Analisa Multifaktor Varian 


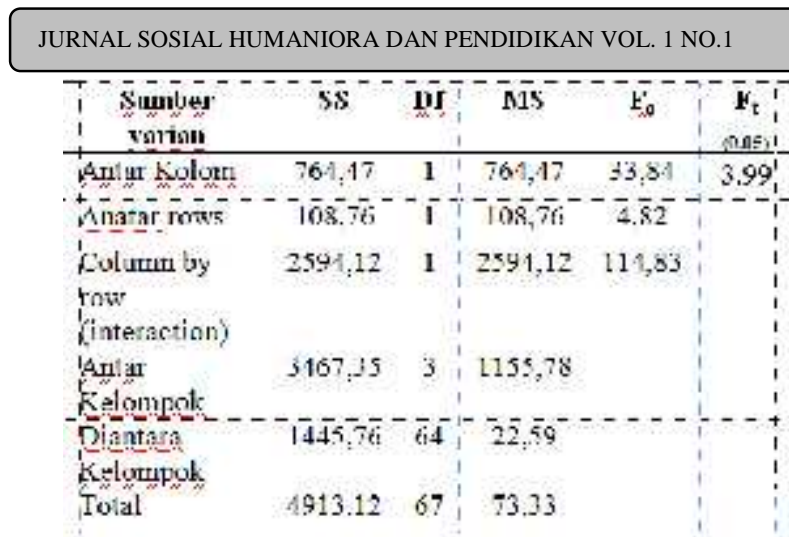

Tabel 2 Nilai Rata- Rata

\begin{tabular}{cccc}
\hline & $\mathbf{A}_{\mathbf{1}}$ & $\mathbf{A}_{\mathbf{2}}$ & \\
\hline $\mathrm{B}_{1}$ & 79,59 & 60,53 & 70,06 \\
$\mathrm{~B}_{2}$ & 64,71 & 70,35 & 67,53 \\
& 72,15 & 65,44 & 68,79 \\
\hline
\end{tabular}

Berdasarkan tabel 1 dan tabel 2 diatas dapat disimpulkan bahwa:

1) Karena $F_{o}$ antar kolom $(33,84)$ lebih besar dari pada $F_{t}$ pada level signifikan $\alpha$ $=0,05(3,99)$, Ho ditolak dan terdapat perbedaan signifikan antar kolom. Ini dapat disimpulkan bahwa terdapat perbedaan signifikan antara kedua model pembelajaran untuk mengajarkan reading comprehension .

2) Karena $F_{\text {row }}$ antar kolom $(4,82)$ lebih besar daripada $F_{\mathrm{t}}$ pada signifikan level $\alpha=$ 0,05 (3,99), Ho ditolak dan terdapat perbedaan signifikan antar kolom. Maka, terdapat perbedaan signifikan antar mahasiswa yang memiliki motivasi belajar tinggi dengan yang rendah dalam kemampuan reading comprehension.

3) Karena F interaction anatar kelompok (114.834) lebih besar daripada $F_{t}$ pada signifikan level $\alpha=0,05(3,99)$. Terdapat interaksi antar model pembelajaran dean motivasi belajar mahasiswa. Hal ini dapat disimpulkan bahwa keefektifan model pembelelajaran tergantung pada tingkat motivsai belajar mahasiswa.

\section{4) Ringkasan Tes Tukey}

Kesimpulan dan penggabungan Tukey tes adalah sebagai berikut:

Tabel 3 Kesimpulan dari Tukey Tes

\begin{tabular}{ccccc}
\hline $\begin{array}{l}\text { Antar } \\
\text { Kelompok }\end{array}$ & $\mathrm{q}_{\mathrm{o}}$ & $\mathrm{q}_{\mathrm{t}}$ & Status & Arti \\
\hline $\mathrm{A}_{1}-\mathrm{A}_{2}$ & 8,23 & 2,89 & Significant & $\mathrm{A}_{1} \neq \mathrm{A}_{2}$ \\
$\mathrm{~B}_{1}-\mathrm{B}_{2}$ & 3,10 & 2,89 & Significant & $\mathrm{B}_{1} \neq \mathrm{B}_{2}$ \\
$\mathrm{~A}_{1} \mathrm{~B}_{1-} \mathrm{A}_{2} \mathrm{~B}_{1}$ & 16,53 & 2,98 & Significant & $\mathrm{A}_{1} \mathrm{~B}_{1} \neq \mathrm{A}_{1} \mathrm{~B}_{1}$ \\
$\mathrm{~A}_{1} \mathrm{~B}_{2-} \mathrm{A}_{2} \mathrm{~B}_{2}$ & 4,90 & 2,98 & Significant & $\mathrm{A}_{1} \mathrm{~B}_{2} \neq \mathrm{A}_{2} \mathrm{~B}_{2}$ \\
\hline
\end{tabular}

1) Karena $q_{o}$ antar kolom $(8,23)$ lebih tinggi daripada $\mathrm{q}_{\mathrm{t}}$ pada level signifikan $\alpha=0,05$ $(2,89)$, terdapat perbedaan signifikan antara model pembelajarn kooperatif Roundtable dengan model pembelajaran langsung untuk mengajarkan reading comprehension pada TOEFL. Karena rata- rata $A_{1}(73,12)$ lebih tinggi dari pada $A_{2}$ (65,82), maka dapat disimpulkan bahwa model pembelajaran kooperatif Roundtable lebih efektif daripada model pembelajaran langsung untuk mengajarkan reading comprehension pada TOEFL.

2) Karena $q_{o}$ antar baris $(3,10)$ lebih tinggi dari pada $\mathrm{q}_{\mathrm{t}}$ pada level signifikan $\alpha=$ 0,05 (2,89), maka dapat disimpulkan 
bahwa terdapat perbedaan signifikan antara mahasiswa yang memiliki motivasi belajar tinggi dan rendah pada kemampuan reading comprehension. Karena rata-rata dari $\mathrm{B}_{1}(69,47)$ lebih tinggi dari pada $\mathrm{B}_{2}(67,91)$, maka dapat disimpulkan bahwa mahasiswa yang memiliki motivasi belajar tinggi memiliki kemampuan reading comprehension lebih baik dari pada mahasiswa yag memiliki motivasi belajar rendah.

3) Karena qo antar cells $\mathrm{A}_{1} \mathrm{~B}_{1}$ and $\mathrm{A}_{2} \mathrm{~B}_{1}$ $(16,53)$ lebih tinggi daripada $\mathrm{q}_{\mathrm{t}}$ pada level signifikan $\alpha=0,05(2,98)$, terdapat perbedaan signifikan dalam penerapan model pembelajaran kooperatif Roundtable untuk mengajarkan reading comprehension untuk mahasiswa yang memiliki motivasi tinggi. Karena rat-rata dari $\mathrm{A}_{1} \mathrm{~B}_{1}(79,26)$ lebih tinggi dari pada $\mathrm{A}_{2} \mathrm{~B}_{1}(60,68)$,maka dapat disimpulkan bahwa model pembelajaran Roundtable lebih efektif daripada model pembelajaran langsung bagi mahasiswa yang memiliki motivasi belajar tinggi.

4) Karena $q_{o}$ antar cells $A_{1} B_{2}$ and $A_{2} B_{2}$ (4.90) lebih tinggi daripada $\mathrm{q}_{\mathrm{t}}$ pada signifikan level $\alpha=0,05(2,98)$, terdapat perbedaan signifikan pada penerapan model pembelajaran langsung untuk mengajarkan reading comprehension pada mahasiswa yang memiliki motivasi belajar rendah.. Karena rata-rata dari $A_{1} B_{2}(64,85)$ lebih rendah daripada $A_{2} B_{2}$ (70,21), maka dapat disimpulkan bahwa model pembelajaran langsung lebih efektif dari pada model pembelajaran kooperatif Roundtable untuk mengajarkan reading comprehension pada mahasiswa yang memiliki motivasi belajar rendah.

Berdasarkan hasil analisa diatas, maka dapat disimpulkan bahwa terdapat interaksi antara model pembelajaran dan motivasi belajar mahasiswa untuk mengajarkan reading comprehension TOEFL karena Fo lebih besar daripada Ft. Terdapat perbedaan signifikan antara model pembelajaran kooperatif Roundtable untuk mengajarkan reading comprehension bagi mahasiswa yang memiliki motivasi tinggi karena $\mathrm{q}_{\mathrm{o}}$ antar cells $\left(A_{1} B_{1}\right.$ dan $\left.A_{2} B_{1}\right)$ lebih tinggi dari pada $\mathrm{q}_{\mathrm{t}}$ dan model pembelajaran kooperatif Roundtable lebih efektif daripada model pembelajarn langsung untuk mengajarkan reading comprehension karena rata - rata dari $A_{1} B_{1}$ dan $A_{2} B_{1}$ lebih tinggi dari $q_{t}$. Terdapat perbedaan signifikan antara model pembelajaran langsung dengan model pembelajaran kooperatif Roundtable untuk mengajarkan reading comprehension bagi mahasiswa yang memiliki motivasi rendah karena $\mathrm{q}_{\mathrm{o}}$ antar 
cells $\left(\mathrm{A}_{2} \mathrm{~B}_{2}\right.$ and $\left.\mathrm{A}_{1} \mathrm{~B}_{2}\right)$ lebih tinggi daripada $\mathrm{q}_{\mathrm{t}}$ dan model pembelajaran langsung lebih efektif daripada model pembelajaran kooperatif Roundtable untuk mengajarkan reading comprehension karena rata- rata dari $\mathrm{A}_{2} \mathrm{~B}_{2}$ lebih tinggi daripada $A_{1} B_{2}$. Keefektifan model pembelajaran tergantung pada tingkat motivasi belajar mahasiswa

\section{Kesimpulan}

Setelah melakukan pembelajaran reading comprehension TOEFL dari kedua kelas baik kelas eksperimen maupun kelas kontrol, maka penulis melakukan analisis data dan mendapatkan kesimpulan bahwa model pembelajaran kooperatif roundtable lebih efektif daripada model pembelajaran langsung untuk mengajar reading comprehension pada TOEFL dan terdapat interaksi antara model pembelajaran dengan motivasi belajar mahasiswa dalamreading comprehension. Untuk mahasiswa yang memiliki motivasi tinggi, model pembelajaran koopertif roundtable lebih efektif daripada model pembelajaran langsung untuk mengajar reading comprehension tetapi untuk mahasiswa yang memiliki motivasi rendah, model pembelajaran langsung lebih efektif daripada model pembelajaran kooperatif roundtable untuk mengajar reading comprehesion. Oleh karena itu, dapat disimpulkan bahwa keefektivitas model pembelajaran tergantung pada tingkat motivasi belajar mahasiswa.

\section{Ucapan Terima Kasih}

Ucapan terima kasih ditujukan pada Direktorat Jenderal Penguatan Riset dan Pengembangan yang telah mendanai penelitian ini dan P3M Polteknik Negeri Balikpapan atas dukungannya dalam menyelesaikan penelitian ini.

\section{Daftar Pustaka}

Arra ,Christopher T., D’Antonio, Mark D., D'Antonio, Mark Jr. 2011. Students"Preferences for Cooperative Learning Approaches: Considerations for College Teachers. Journal of Research in Education. 21 (1): 114-126.

Borrich, Gary D. 1996. Effective Teaching Methods. 3rd Prentice Hall. New Jersey: Inc. Budiyono. 2003. Metodologi Penelitian. Surakarta: UNS Press.

Duff, J. 2012. Cooperative Learning Vs. Direct Instruction: Using Two Instructional Models To Determine Their Impact On Students Learning In A Miiddle School. Education Senior Action Research Projects. Paper 5.

Elliot, Stephen. 2000. Educational Psychology: Effective Teaching Effective Learning.California: McGraw Hill Company.

Hamzah B. Uno. 2008. Teori Motivasi dan Pengukurannya. Jakarta : Bumi Aksara.

Johnson, Burke and Christensen, Larry. 2000. Educational Research. Quantitative and Qualitative Approach. Santiago: A Pearson Education Company.

Kagan S. 2009. Kagan Cooperative Learning. San Clemente, CA: Kagan Publishing. Lundgren, L. 1994. Cooperative Learning in the Science Classroom. New York: JICA.

Philips, Deborah. 2001. Longman Complete Course for the TOEFL Test: Preparation 
for the Computer and Paper Test. New York: A Person Education Company.

Sardiman, A.M. 2004. Interaksi dan Motivasi Belajar Mengajar. Jakarta: Radja Grafindo Persada.

Tuckman, Bruce W. 1978. Conducting Education Research.

New York: Harcourt Brace Jovanivich, Inc. 